\title{
AN ANTHROPOLOGICAL ANALYSIS ON THE CASUISTRY OF THE EMERGENCY MEDICAL SERVICE
}

\author{
Adina Baciu \\ The Institute of Anthropology „Francisc I. Rainer” of the Romanian Academy, Bucharest Bd. \\ Bucharest, Romania
}

\section{Summary}

The objective of this study is to observe the contribution of the current distribution of diseases in a group of patients from the urban area, considering their sex and age, contribution which is visible in the emergency medical service and the importance of the computed-tomography in the process of diagnosing.

This cross-sectional study was taken during two months in the emergency medical service of Bucharest, studying a group of 600 patients (236 women, 364 men), 1-92 years of age, based on the diagnostics agreed when the subjects concerned had been hospitalized and the computed-tomography had already completed. The results were processed using statistical methods.

$27.12 \%$ of women involved were diagnosed with tumor conditions and $20.60 \%$ of the men involved were diagnosed with CCT. $27.78 \%$ of men above 80 years of age usually need emergency medical services because of intracranial expansive processes and cerebral vascular accidents (strokes). The percentage of women $(55.17 \%)$ having tumors is higher than that of men included in the study $(44.83 \%)$, the difference being statistically significant $(\mathrm{p}<0.05)$.

This study reveals that men under the age of 60 and women under the age of 40 are affected by traumas, in comparison with the people of both sexes over this age, for whom the most frequent diseases visible are tumors. Consequently, we consider that it is necessary to promote the primary prevention method, to fight the risk factors, so that such severe conditions are avoided.

Key words: medical anthropology, pathology, urgency.

\section{Introduction}

The objectives of this study are to observe the contribution of the current distribution of diseases in a group of patients from the urban area, considering their sex and age, contribution which is visible in the emergency medical service, the importance of the computed-tomography (CT) in making a diagnosis, as well as the importance of proposing measures so that these new diseases with severe consequences are avoided in the future.

Crania-cerebral traumatisms (CCT) and their effects represent a major issue of the public health context, being defined as the cause of approximately two-thirds of the traumatic deaths and the most common generator of the post-traumatic permanent disability (http://www.google.ro/ url $2 \mathrm{sa}=\mathrm{t} \& \mathrm{rct}=\mathrm{j} \& \mathrm{q}=\&$ esrc $=\mathrm{s} \&$ source $=$ web $\& \mathrm{~cd}=2 \& \mathrm{sqi}=2 \& \mathrm{ved}=0 \mathrm{CC} 8 \mathrm{QFj} \mathrm{AB} \& u r l=\mathrm{http} \% 3 \mathrm{~A} \% 2 \mathrm{~F} \%$ 2Fwww.cursurimedicina.ro\%2Ffiles \%2FCurs\%2520I\%2520-\%2520studenti\%2520-\%2520 traumatologie\%2520craniocerebrala.doc\&ei=QRZCUaOxE4jGPOuHgNgI\&usg=AFQjCNFKJN NGYGAKlvxmXSWk8WYC4Oq9Qw\&bvm=bv.43287494,d.ZWU). Being considered a routine in examining patients, the computed tomography consultation is indispensable for the imaging evaluation of the patients who suffer from crania-cerebral traumatisms (CCT), for various reasons. Some of them are focused on the poor performance of the other imaging examination methods in tracing the trauma lesions. At the same time, the temptation of examining all the 
patients who suffer from cranial traumatisms through CT, no matter the gravity of their health status, is a cause of frequent abuses of the method, with potentially severe effects on the patient's health, considering the cariokinetogen possibility of irradiation (Santa and Santa, 2007).

Poly-traumas need to be considered a complex clinic lesion entity, which may evolve in time and which imply multiple therapeutic issues. Presently, the emergency pathology is dominated by poly-traumas. The main traumas are caused by road accidents, followed closely by the ones caused by industrial accidents, fall accidents of different kinds and the ones caused by multiple factors. It is hard to agree on the real incidence of poly-traumas (Constantinovici and Ciurea, 1998). Also, overweight, obesity and changes in fat distribution are associated with higher risk of chronic diseases such as arteriosclerosis, coronary arterial disease and cancers (Pavlica et al., 2010). There has been a significant increase in the prevalence of overweight and obesity in many countries in the world (WHO, 2000), and in surrounding area (Pavlica et al., 2014).

At the beginning of the $21^{\text {st }}$ century, cancer continues to be one of the most severe diseases confronting human beings. Because of its anticipation on the future context, with common demoralizing consequences and human, economic and social involvement, the image of cancer is the darkest one, in comparison with other well-known diseases, the myth that it is incurable and very severe is also familiar to us. The experience and knowledge cumulated in the past 20 years have started to dethrone this myth of weakness and emphasize the possible activities that could treat this condition. The incidence of cancer has had an impressive spreading in the past years, being known as the third mortal disease, apart from cardio-vascular and other accidents. Romania has a cancer mortality rate of $143.3 \%$ (meaning 143. 3 of 100.000 subjects) and is currently a part of the group of countries with an average mortality rate. In the past century, between 1932-1987, the mortality rate caused by malign tumors had increased continually, from $36.9^{0} / 0000$ to $136 \% / 0000$ deceases (https://docs.google.com/viewer?a=v\&q=cache:DosUHyoGj68J:www.srccjro.org/revista\%25 20pdf/nr\%25201/incidenta\%2520cancerului $\% 2520 \mathrm{in} \% 2520$ romania15.pdf $+\& \mathrm{hl}=\mathrm{ro} \& \mathrm{gl}=\mathrm{ro}$ \&pid=bl\&srcid=ADGEESh7XukAU9_-q1GKbZT46GZr9jFNoHZKil-GceSHAjgc-r1nCdHhSG cjFtndhwc4eoLP766BKJY86OnmyEVg_liDIndVGrVbcJ94mw3mn4QC2Ygol88aW--lbI03 GCkk52HjFVBE\&sig=AHIEtbR4ikyRgQ_qKE_um6G10jA7IIQ0TQ).

The expansive intracranial process (EICP) is defined as any process considered a space replacement developed in the skull, no matter its origin: tumors, blood collections (hematomas), arterial-venous malformations, inflammatory expansive processes (abscesses, empyema, and tuberculoma), parasites, pseudo-tumors. More than half of the EICP cases are tumors (Constantinovici and Ciurea, 1998, Ciurea, 2010). The intracranial primary tumors, related to other tumors spread in the organism, represent $8 \%$ of the total number, while the cerebral metastasis represent $25 \%$, which is shown by a continuous increase of the percentage in the past years (Teddy, 1989).

The cerebral vascular accidents (CVA) represent the most important chapter in the pathology of the brain, considering the increased frequency and the gravity of the cerebral disorders generated by them, which usually do not have any cure. They are known as the third most important cause of mortality, besides the cardio-vascular and neoplasia disease and, as well as the top neurological diseases of the past years (http://art-zone.ro/boli/ accidentul_vascular_cerebral_avc_atacul_cerebral_tratament_cauze_simptome.html). In the southeastern Europe, the mortality rate caused by this disease is six-seven time bigger than in the eastern countries. Our country has a top spot in this chapter. One questionnaire, designed for 805 people (over 45 years), $72 \%$ answered that they have suffered from this disease or they knew one person affected by it. Annually, every fifth decease is caused by a cerebral vascular accident (http://www.referat.ro/referate_despre/accidentul_vascular_cerebral_referat.html). Deaths also included in the cerebral vascular accident category are bleeding and ischemia (local decrease of the blood's flow, due to a spasm), opposite pathological processes, ischemia being often visible, in $70 \%$ of the cases (http://art-zone.ro/boli/accidentul_vascular_cerebral_avc_atacul_ cerebral_tratament_cauze_simptome.html). 


\section{Materials and methods}

This cross-sectional study was taken during a two month-period in the emergency medical service of Bucharest, studying a group of 600 patients $(39.33 \%$ women, $60.67 \%$ men), 1-92 years of age. For a better anthropological relevance, we took into account age categories from 10 to 10 , or 20 to 20 years. The diseases registered for the patients that had used the emergency medical service were mainly: crania-cerebral traumatisms (CCT), polytraumas, tumours (abdominal, gastric, ovarian or prostate tumours, renal, colon tumours, hepatic, pancreatic, pulmonary or any other tumours, localized in the human body), intracranial expansive processes (EICP), cerebral vascular accidents (CVA), the sub-occlusive syndrome, pancreatitis (acute or chronic), along with other diseases.

The results were processed through statistical methods. The statistical processing of the existing data was framed into a "database" - initially in an Excel format, subsequently in an EPI INFO format. This study uses graphics and tables to gather the results.

The ethical norms of a scientific study were also used in this study, and the anonymity and confidentiality rules were obeyed.

\section{Results}

The percentage of men $(60.67 \%)$ who presented themselves at the emergency medical service is bigger than that of women $(39.33 \%)$, according to Figure 1.

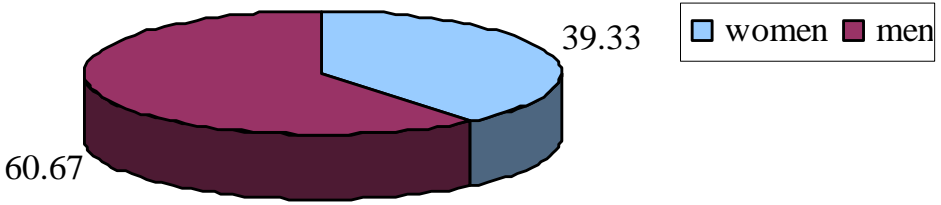

Figure 1. The structural division of the studied group based on their gender Grafikon 1. Strukturalna podela studijske grupe na osnovu pola

If we analyzing Table 1 we can conclude that most women who used the emergency medical service $(27.12 \%)$ were diagnosed with tumors of different localizations, while CCT $(20.60 \%)$ is common for the men in the studied group.

Table 1. The structure of the studied group, based on their gender and the associated diseases

Tabela 1. Struktura studijske grupe na osnovu pola i povezanih bolesti

\begin{tabular}{lrrrr}
\hline Disease & \multicolumn{2}{c}{ Women } & \multicolumn{2}{c}{ Men } \\
\cline { 2 - 5 } & $\mathrm{N}$ & \multicolumn{1}{c}{$\%$} & \multicolumn{1}{c}{ N } \\
\hline Tumors & 64 & $\mathbf{2 7 . 1 2}$ & 52 & 14.29 \\
Sub-occlusive syndrome & 10 & 4.24 & 9 & 2.47 \\
EICP & 26 & 11.02 & 52 & 14.29 \\
CVA & 27 & 11.44 & 52 & 14.29 \\
Poly-traumas & 25 & 10.59 & 60 & 16.48 \\
Pancreatitis & 27 & 11.44 & 38 & 10.44 \\
CCT & 33 & 13.98 & 75 & $\mathbf{2 0 . 6 0}$ \\
Other diseases & 24 & 10.17 & 26 & 7.14 \\
\hline Total & 236 & 100 & 364 & 100 \\
\hline
\end{tabular}


Analyzing Table 2 we conclude that $59.26 \%$ of men under 20 years of age and $33.33 \%$ of men between 20-39 years of age use the emergency medical service for CCT. $18 \%$ of men between $40-59$ years of age use the service to fight poly-traumas, while $28.30 \%$ of the patients between $60-79$ years of age use it for tumors. $27.78 \%$ of men over 80 years of age are included in the emergency service due to EICP and CVA diseases.

Table 2. The structure of the men from the studied group based on pathology and age category Tabela 2. Struktura muškaraca studijske grupe na osnovu patologije $i$ starosne dobi

\begin{tabular}{|c|c|c|c|c|c|c|c|c|c|c|c|}
\hline \multirow{2}{*}{ Disease } & \multicolumn{2}{|c|}{$>20$ years } & \multicolumn{2}{|c|}{ 20-39 years } & \multicolumn{2}{|c|}{$40-59$ years } & \multicolumn{2}{|c|}{$60-79$ years } & \multicolumn{2}{|c|}{$<80$ years } & \multirow{2}{*}{ Total } \\
\hline & $\mathrm{N}$ & $\%$ & $\mathrm{~N}$ & $\%$ & $\mathrm{~N}$ & $\%$ & $\mathrm{~N}$ & $\%$ & $\mathrm{~N}$ & $\%$ & \\
\hline Tumors & & & 3 & 3.23 & 15 & 12.50 & 30 & 28.30 & 4 & 22.22 & 52 \\
\hline Sub-occlusive syndrome & & & 1 & 1.08 & 5 & 4.17 & 2 & 1.89 & 1 & 5.56 & 9 \\
\hline EICP & 4 & 14.81 & 16 & 17.20 & 16 & 13.33 & 11 & 10.38 & 5 & 27.78 & 52 \\
\hline CVA & & & 5 & 5.38 & 15 & 12.50 & 27 & 25.47 & 5 & 27.78 & 52 \\
\hline Poly-traumas & 5 & 18.52 & 20 & 21.51 & 22 & 18.33 & 13 & 12.26 & & & 60 \\
\hline Pancreatitis & & & 10 & 10.75 & 16 & 13.33 & 12 & 11.32 & & & 38 \\
\hline CCT & 16 & 59.26 & 31 & 33.33 & 19 & 15.83 & 6 & 5.66 & 3 & 16.67 & 75 \\
\hline Other diseases & 2 & 7.41 & 7 & 7.53 & 12 & 10.00 & 5 & 4.72 & & & 26 \\
\hline Total & 27 & 100.00 & 93 & 100.00 & 120 & 100.00 & 106 & 100.00 & 18 & 100.00 & 364 \\
\hline
\end{tabular}

Table 3 shows that $33.33 \%$ of women under 20 years of age and $20.00 \%$ of women between 20-39 years of age use the emergency medical service because of CCT. 17.91\% of women between 40-59 years of age use it due to EICP. Starting at the age of 60, approximately $40.00 \%$ of women use the emergency medical service because of tumors and any related complications.

Table 3. The structure of the women studied based on their diseases and age category Tabela 3. Struktura žena studijske grupe na osnovu njihovih bolesti i starosne dobi

\begin{tabular}{|c|c|c|c|c|c|c|c|c|c|c|c|}
\hline \multirow[t]{2}{*}{ Disease } & \multicolumn{2}{|c|}{$>20$ years } & \multicolumn{2}{|c|}{$20-39$ years } & \multicolumn{2}{|c|}{$40-59$ years } & \multicolumn{2}{|c|}{$60-79$ years } & \multicolumn{2}{|c|}{$<80$ years } & \multirow[t]{2}{*}{ Total } \\
\hline & $\mathrm{N}$ & $\%$ & $\mathrm{~N}$ & $\%$ & $\mathrm{~N}$ & $\%$ & $\mathrm{~N}$ & $\%$ & $\mathrm{~N}$ & $\%$ & \\
\hline Tumors & & & 6 & 15.00 & 11 & 16.42 & 39 & 40.21 & 8 & 40.00 & 64 \\
\hline Sub-occlusive syndrome & & & 1 & 2.50 & 2 & 2.99 & 5 & 5.15 & 2 & 10.00 & 10 \\
\hline EICP & 2 & 16.67 & 7 & 17.50 & 12 & 17.91 & 2 & 2.06 & 3 & 15.00 & 26 \\
\hline CVA & & & 2 & 5.00 & 8 & 11.94 & 16 & 16.49 & 1 & 5.00 & 27 \\
\hline Poly-traumas & 3 & 25.00 & 7 & 17.50 & 11 & 16.42 & 4 & 4.12 & & & 25 \\
\hline Pancreatitis & 1 & 8.33 & 2 & 5.00 & 8 & 11.94 & 15 & 15.46 & 1 & 5.00 & 27 \\
\hline CCT & 4 & 33.33 & 8 & 20.00 & 9 & 13.43 & 9 & 9.28 & 3 & 15.00 & 33 \\
\hline Other diseases & 2 & 16.67 & 7 & 17.50 & 6 & 8.96 & 7 & 7.22 & 2 & 10.00 & 24 \\
\hline Total & 12 & 100 & 40 & 100 & 67 & 100 & 97 & 100 & 20 & 100 & 236 \\
\hline
\end{tabular}

Figure 2 shows that the percentage of women with tumors of different localizations and complications $(55.17 \%)$ use the emergency medical services more than men with the same condition $(44.83 \%)$, the difference being statistically significant $(\mathrm{p}<0.05)$. We have also included malignant tumors in the tumors category, because they are the most frequent.

Figure 3 concludes that the most frequent tumors visible in women who used the emergency medical service are the hepatic tumors $(25.00 \%)$, while the most frequent ones in men are the pulmonary tumors $(28.85 \%)$. 


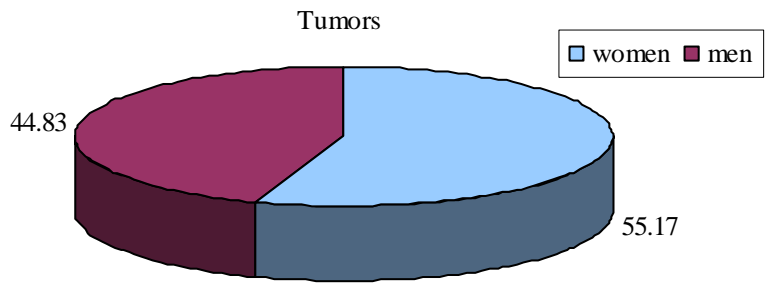

Figure 2. The structural distribution of the group with tumors, based on their gender Grafikon 2. Struktura rasprostranjenosti tumora u grupi na osnovu pola

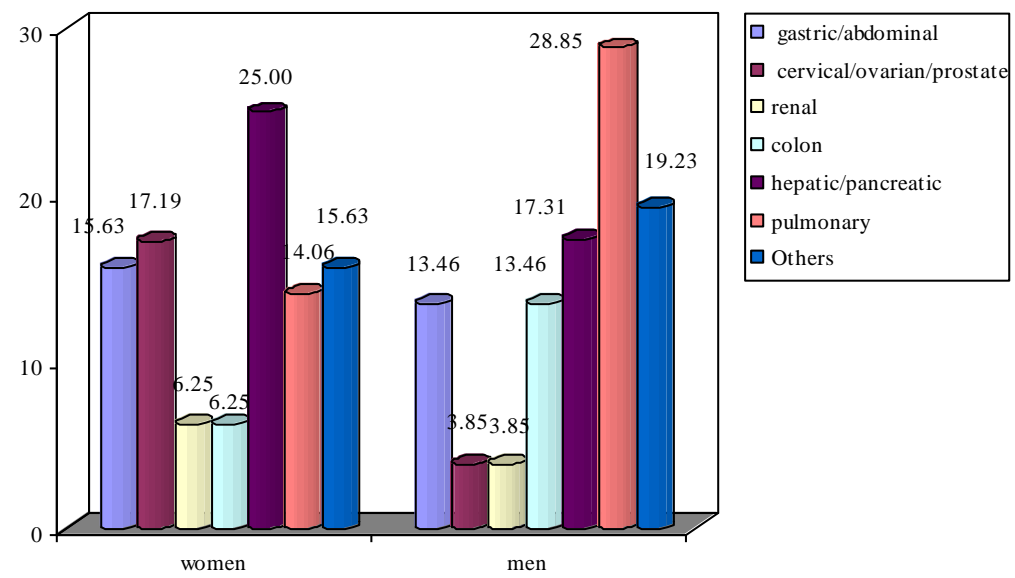

Figure 3. The structural division of the patients with tumors, based on their gender and tumor localization

Grafikon 3. Strukturalna podela pacijenata koji imaju tumor, na osnovu pola i lokalizacije tumora

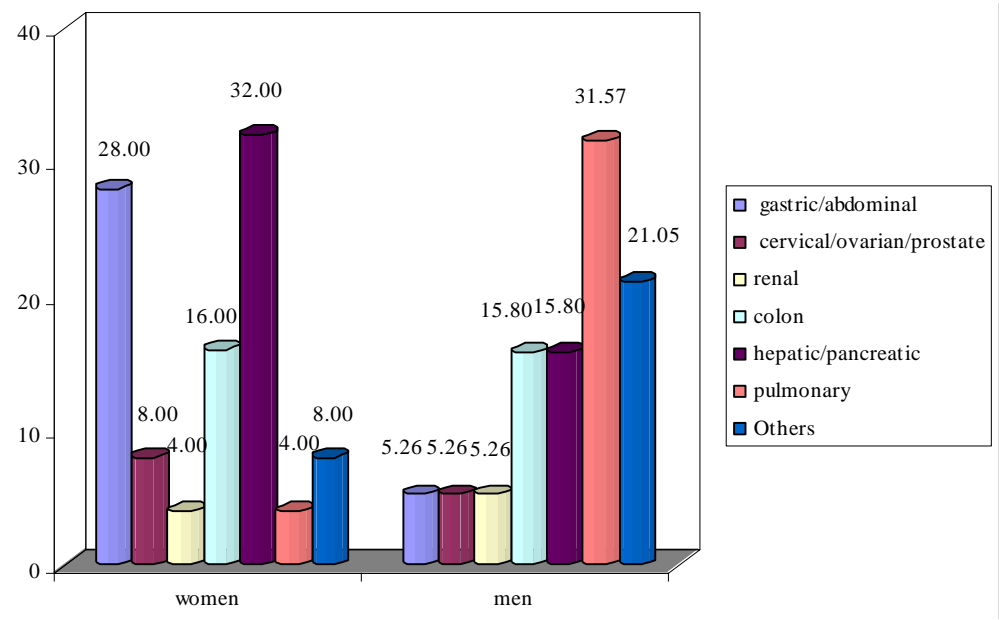

Figure 4. The structural division of the studied group with tumors based on their gender and the tumor localization for patients between 60-69 years of age

Grafikon 4. Strukturalna podela pacijenata starosne dobi 60-69 godina u studijskoj grupi koji imaju tumor, na osnovu pola i lokalizacije tumora 
Figure 4 shows that $32.00 \%$ of the women between $60-69$ years of age have hepatic cancer and $31.57 \%$ of the men studied have a pulmonary cancer condition. We have chosen this age category because the incidence of tumors for both the women and men studied is the highest at this age. In Romania, breast cancer and cervical cancer have an incidence of $28 \%$ ooo and $20 \%$ ooo), but our study shows that most women suffer from hepatic cancer. For men of this age pulmonary cancer has an incidence of $67 \% 0_{00}$, in our study the percentage is lower.

\section{Discussion}

Our study includes more men than women, the majority of them use the emergency medical service in the CCT time frame, the percentage is lower (20.60\%) than the one emphasized through the Neurotrauma investigation. Recent statistics from the USA and Germany show an incidence of 200-300 cases of CCT calculated for 100.000 residents, the top being embodied by the age category of 15-24 years of age and the predominance of men in comparison with women being visible as 2-4/1. Considering the case of the poly-traumatized patients, 50\% present lesions of SNC, and CCT is visible for $75 \%$ of the people deceased after road accidents. In Romania, the preliminary investigations performed by the Neurotrauma group of SRN in 1997 highlighted a 2995\% share of CCT in the specialized Romanian departments and a mortality rate in severe CCT cases of 60-90\%, while the same indicator had a share of 31\% in the European countries in 1996 (Traumatologie cranio-cerebrala http://www.google.ro/url? sa=t\&rct=j\&q=\&esrc=s\&source= web $\&$ cd $=2 \&$ sqi $=2 \&$ ved $=0 \mathrm{CC} 8 \mathrm{QFj} \mathrm{AB} \&$ url $=\mathrm{http} \% 3 \mathrm{~A} \% 2 \mathrm{~F} \% 2 \mathrm{Fwww}$.cursurimedicina.ro $\% 2 \mathrm{Ffil}$ es $\% 2$ FCurs $\% 2520 \mathrm{I} \% 2520-\% 2520$ studenti $\% 2520 \% 2520$ traumatologie $\% 2520$ craniocerebrala. doc\&ei=QRZCUaOxE4jGPOuHgNgI\&usg=AFQjCNFKJNNGYGAKlvxmXSWk8WYC4Oq 9Qw\&bvm=bv.43287494,d.ZWU).

CCT is the most common pathology of the patients studied, regardless of sex, for people under 40 years of age $59.26 \%$ of the men included and $33.33 \%$ of the women under the age of 20 , in comparison with $33.33 \%$ of men and $20.00 \%$ of women $20-39$ years of age), the percentage being higher for men. The majority of patients who suffer from this pathology are adolescents, young adults and elderly men (>75 years). If we analyze the elderly patients (over 65 years) the main cause is represented by fall accidents (from height or common), while for the groups of young patients the main causes are road accidents (Iordache, sine anno).

Between 40-59 years of age, a larger percentage of the diagnosed patients of the study ( $18.33 \%$ men and $16.42 \%$ women) suffer from poly-traumas. We need to mention that the statistical data shows that road accidents are the main cause of death of people under the age of 40 (Steedman, 1990).

Based on the current study, it is emphasized that the most frequent malign tumors are the following: pulmonary, hepatic, cervical, gastric, colon and renal. Consequently, the most frequent localizations of cancer are: stomach, lungs, breast, colon, rectum, cervix (The incidence of cancer in Romania https://docs.google.com/viewer? $\mathrm{a}=\mathrm{v} \& \mathrm{q}=$ cache:DosUHyoGj68J: www.srccjro.org/revista\%2520pdf/nr\%25201/incidenta\%2520cancerului\%2520in\%2520romania 15.pdf $+\& h l=$ ro\&gl=ro\&pid=bl\&srcid=ADGEESh7XukAU9-q1GKbZT46GZr9jFNoHZKilGceSHAjgc-r1nCdHhSGcjFtndhwc4eoLP766BKJY86OnmyEVg_liDIndVGrVbcJ94mw3mn 4QC2Ygol88aW--lbI03GCkk52HjFVBE\&sig=AHIEtbR4ikyRgQ_qKE_um6Gl0jA7IIQ0TQ).

From all the types of cancer, the one that causes the greatest number of deaths is the pulmonary cancer, around 1.2 million at global level. The statistics related to this illness show that, globally, a person dies of lung cancer every 30 seconds. In Romania, the incidence of pulmonary cancer in comparison with other cancerous tumors is high, with more than 7300 people registered annually. Men from our country are most frequently diagnosed with lung cancer. If we analyze the incidence of such cancer type in women, this disease takes the 
fourth place, after breast, cervical and colorectal cancer (http://www.medipedia.ro/Articole/ tabid/70/articleType/ArticleView/articleId/3373/Cancerul-pulmonar-incidenta-mare-barbatii.aspx).

This study highlights that $28.85 \%$ of men and $14.06 \%$ of women were diagnosed with lung cancer after the CT examination. $31.57 \%$ of men and $4.00 \%$ of women $60-69$ years of age suffer from pulmonary cancer.

In our country, lung cancer is at the top of the list, if we take into consideration both the incidence and the mortality rate. Yet, quitting the smoking habit would avoid 9 of 10 cancer incidences. The frequency gets greater in the case of women, along with the largest number of female smokers (http://oanapop.wordpress.com/tag/fumat-fum-incidenta-cancer-pulmonar-nicotina).

In the European Union, the annual incidence of lung cancer is 52.5/100.000 people per year and the annual mortality is $48.7 / 100.000$ people per year. The numbers for men are: an incidence of $82.5 / 100.000$ and a mortality rate of $77 / 100.000$, while for women the incidence is 23.9/100.000 and a mortality rate of 22.3/100.000 (http://www.imparte.ro/Statistici/ Statistici-pentru-cancerul-pulmonar-40.html).

$25 \%$ of the women and $17.31 \%$ of the men studied were diagnosed with hepatic carcinoma and liver metastases. In 60-69 age group, 32.00\% of the women and $15.80 \%$ of the men present malignant liver tumors. Epidemiological studies emphasize a continuous growth of liver tumors annually at global level: 500.000-1.000.000 new cases of hepatic carcinoma, adding numerous other cases of liver metastases. Men are more frequently affected than women. The average age of such cases is smaller (33 years) in the countries with a low incidence of the disease (50-62 years) (Gherasim, 1999).

In our study, there were fewer cases of breast cancer visible, a lot of the patients suffering from metastases at different organs. The liver metastases of breast cancer are rare, but their presence does not always indicate an unfavorable prognosis. They are commonly associated with bones metastases (Tîâcoveanu et al., 2008). Approximately 50\% of ill women suffering from breast malignant tumors will develop metastases in different organs, this being the main cause of death for women. Of the total number of women patients recently diagnosed, only $15 \%$ suffer from liver metastases, $1 / 3$ showing liver metastases. Of the number of patients with malignant tumors stage IV, almost $50 \%$ will develop liver metastases, with the average survival rate from 3 to 15 months (Adam et al., 2006).

Based on this study, we analyzed separately EICP from tumors, because we needed to follow the hospitalization diagnose established after the CT examination, which, being an emergency service, does not present the nature of the space replacement process in the brain box. Once the CT scan (computed tomography) and the NMR (nuclear magnetic resonance) were introduced as routine examinations, diagnosing intracranial tumors became much faster and more accurate regarding the histopathological specificity. Under these conditions, the incidence has become impressively greater in the last 15 years, regardless of age. Over 70 years, due to the actual neuro-imagistic investigation, the incidence of intracranial tumors was raised from 5.7 to 19.1 on a scale of 100.000 residents (Helseth, 1995). The study also emphasizes that $27.78 \%$ of men and $15.00 \%$ of women over 80 years start investigations for EICP. Intracranial tumors are twice more frequent among men. (Constantinovici and Ciurea, 1998).

Regarding the patients between 40-59 years of age, we notice that a larger percentage $(17.91 \%)$ of the women, in comparison with the men studied $(13.33 \%)$, is diagnosed with EICP. In the case of the patients over the age of 40, we may notice malignant astrocytomas, metastases and meningiomas, while women are often diagnosed with meningiomas and pituitary tumors (Constantinovici and Ciurea, 1998). Specialized literature emphasizes that for the people 40-60 years of age, the incidence of meningiomas is of $18.5 \%$ (Teddy, 1989).

$12.5 \%$ of men and $11.94 \%$ of women $40-59$ years of age are diagnosed with CVA. Starting with the age of 60 to $70,25.47 \%$ of the men and $16.49 \%$ of the women included in the study use the medical service due to CVA symptoms. The risk of the cerebral vascular accident is growing with age. The risk actually gets doubled with each decade for people 
above 55 years of age. At least $66 \%$ of the people who suffer from CVA are 65 or over 65 years of age. The cerebral vascular accident is more frequent in the case of men, in comparison with women for people under the age of 75 , but above this age, women are a prime target for the disease. No matter the age, more women than men die from AVC (http://www.sfatulmedicului.ro/Accidentul-vascular-cerebral/accidentul-vascular-cerebral-avc_314). Our study shows that $27.78 \%$ of men and only $5 \%$ of women over 80 are diagnosed with CVA.

The majority of men diagnosed with pancreatitis in this study $(13.33 \%)$, are $40-59$ years of age. The frequent cause of chronical pancreatitis of an adult is chronical alcoholism. Alcoholism is more frequent in men. Consequently, the chronical pancreatitis is often seen as a male disease, mainly for the ones 34-49 years of age (Gherasim, 1999).

This study emphasizes that the pancreatitis cases are detected in younger women $(8.33 \%$ of women under the age of 20), the highest percentage (15.46\%) is detected in women 60-79 years of age. In the case of elderly people, if we take women's situation, the first acute pancreatitis attack is usually caused by lithiasis (stones). The gallstones may appear in childhood, but the frequency grows in the course of time for people above the age of $60,35 \%$ of women and $20 \%$ of men. In Romania, the biliary lithiasis is detected in $8.4 \%$ of women and $5 \%$ of men. Gallstones and alcoholism are the main cause of at least $80 \%$ of the acute pancreatitis cases. $3 \%$ of the pancreas cancers display the same symptoms as the acute pancreatitis (Gherasim, 1999).

During this study, the sub-occlusive syndrome is visible in the lower percentage of men, while $10.00 \%$ of women above the age of 80 are diagnosed with this disease.

\section{Conclusion}

Based on this study, analyzing the process of the emergency medical service used for this paper, we may notice the following:

- For men under the age of 60 , traumas are frequent, above this age the pathology being even more common than the tumor one;

- Traumas dominate the pathology of women under the age of 40 , above this age the primary tumors or metastasis with different localizations are more often;

- The computed tomography (CT), even if it is more expensive and implies a longer period of time for examination, it is more and more applied in the emergency medical services, the new medical equipment and the use of contrasting medical substances have a positive result in the field;

- The pathology of the emergency medical services (poly-traumas, especially seen after road accidents, CCT, CVA, malignant tumors with metastasis) raises an important social issue, having as a result high costs for the health services, due to the injuries of the patients who survive the accidents. Consequently, we consider more than necessary to promote the primary prophylaxis, so that the risk factors that may cause such diseases with severe effects are avoided.

Acknowledgements. Special thanks go to Mihaela Pavel for her contribution in having this study completed. 


\section{References}

Adam R, Aloia T, Krissat J, Bralet MP, Paule B, Giacchetti S, Delvart V, Azoulay D, Bismuth H, Castaing D. Is Liver Resection Justified for Patients With Hepatic Metastases From Breast Cancer? Ann Surg. 2006 December; 244(6): 897-908.

Ciurea A.V. Treaty of neurosurgery, Bucureşti: Medical Edition. 2010; Vol.I.

Constantinovici A., Ciurea A.V. Practical guide to neuro-surgery. București: Editura Medicală. 1998: 164, 193-194

Gherasim L. Internal medicine. Bucureşti: Editura Medicală. 1999; Vol. III: 977-979, 1013-1043, 1091.

Helseth A. The incidence of primary central nervous system neoplasm before and after computerized tomography availability. J. Neuroserg., 1995; 83: 999-1 003.

Iordache A. C. Modern management of severe crania cerebral traumatisms. PhD Thesis, UMF «r.T.Popa». sine anno.

Pavlica T., Božić-Krstić V., Rakić R. Body mass index, waist-to-hip ratio and waist/height in adult population from Backa and Banat-the Republic of Serbia. Ann Hum Biol, 2010; 37(4):562-573.

Pavlica T., Rakić R., Sakač D. Anthropometric Indices of Obesity and Potential Health Risk in adult Rural Population from Bačka and Banat - The Republic of Serbia. Coll. Antropol.2014; 1: 227-233.

Santa A., Santa Carmen. The CT examination in cranian trauma. „Sibiul Medical“. 2007; 18-3: 29-32.

Steedman D.J. Medical teams for accidents and major disaters. Injury, 1990; 21: 206-208.

Teddy P.J. Intracranial tumors. Oxford Medical Publications. 1989; Vol.II.

Tîacoveanu E, Vasilescu A, Zugun-Eloae F, Giuşcă Simona, Căruntu Irina Draga, Carasievici E. The hepatic metastases of breast cancer. Jurnal of surgery, Iaşi, 2008; Vol. 4, Nr. 3 [ISSN 1584 - 9341]: 201-216.

World Health Organization. WHO. 2000. Obesity: Preventing and managing the global epidemic. Technical report series no. 894. Geneva:

Traumatologie cranio-cerebrala http://www.google.ro/url?sa=t\&rct=j\&q=\&esrc=s\&source=web\&cd= $2 \&$ sqi $=2 \&$ ved $=0 \mathrm{CC} 8 \mathrm{QFjAB} \& u r l=\mathrm{http} \% 3 \mathrm{~A} \% 2 \mathrm{~F} \% 2 \mathrm{Fwww}$. cursurimedicina.ro $\% 2 \mathrm{Ffiles} \% 2 \mathrm{FCurs} \% 2$ $520 \mathrm{\%} \% 2520-\% 2520$ studenti $\% 2520-\% 2520$ traumatologie $\% 2520$ craniocerebrala.doc\&ei=QRZCUaO xE4jGPOuHgNgI\&usg=AFQjCNFKJNNGYGAKlvxmXSWk8WYC4Oq9Qw\&bvm=bv.43287494,d.Z WU. Accessed March 14. 2013.

Babici R. The incidence of cancer in Romania. Available at: https://docs.google.com/viewer?a=v\&q=cache:DosUHyoGj68J:www.srccjro.org/revista\%2520pdf/ nr\%25201/incidenta\%2520cancerului\%2520in\%2520romania15.pdf $+\&$ hl=ro\&gl=ro\&pid=bl\&srcid =ADGEESh7XukAU9_-q1GKbZT46GZr9jFNoHZKil-GceSHAjgc-r1nCdHhSGcjFtndhwc4eoLP766 BKJY86OnmyEVg_liDIndVGrVbcJ94mw3mn4QC2Ygol88aW--lbI03GCkk52HjFVBE\&sig=AHIE tbR4ikyRgQ_qKE_um6Gl0jA7IIQ0TQ. Accessed March 17. 2013

Accidentale vasculare cerebrale ishemice, cauze, simptome, tratament. Available at: http://artzone.ro/boli/accidentul_vascular_cerebral_avc_atacul_cerebral_tratament_cauze_simptome.html Accessed March 16. 2013.

Accidentale vasculare cerebrale. Available at: http://www.referat.ro/referate_despre/accidentul_vascular_ cerebral_referat.html. Accessed March 16. 2013

Cancelur pulmonar, incidenta mare la bârbati Romani. Available at: http://www.medipedia.ro/ Articole/tabid/70/articleType/ArticleView/articleId/3373/Cancerul-pulmonar-incidenta-marebarbatii.aspx. Accessed March 14. 2013

The carcinoid cancer foundation. Available at: http://oanapop.wordpress.com/tag/fumat-fum-incidentacancer-pulmonar-nicotina. Accessed March 14. 2013

Statistici pentru cancerul pulmonar. Available at: http://www.imparte.ro/Statistici/Statistici-pentrucancerul-pulmonar-40.html. Accessed March 14. 2013

Accidental vascular cerebral (AVC). Available at: http://www.sfatulmedicului.ro/Accidentul-vascularcerebral/accidentul-vascular-cerebral-avc_314. Accessed March 16. 2013. 


\title{
ANTROPOLOŠKA ANALIZA KAUZISTIKE U SLUŽBI HITNE MEDICINSKE POMOĆI
}

\author{
Adina Baciu
}

\section{Sažetak}

Cilj ove studije bio je ispitati uticaj trenutne rasporostranjenosti bolesti u okviru grupe pacijenata iz urbane sredine, uzevši u obzir njihov pol i starosnu dob, uticaj koji se može uočiti u okviru pružanja hitnih medicinskih usluga kao i značaj kompjuterizovane tomografije prilikom postavljanja dijagnoze.

Ova transverzalna studija sprovedena je u periodu od dva meseca provedenih u službi hitne medicinske pomoći u Bukureštu, studijom je obuhvaćeno 600 pacijenata (236 žena, 364 muškaraca), starosti 1-92 godine, zasnovana na dijagnostici postavljenoj kada je dati pacijent hospitalizovan i nakon što je odrađena kompjuterizovana topografija. Prilikom obrade podataka korišćene su statističke metode.

Kod 27,12\% žena koje su učestvovle u studiji, dijagnostikovan je tumor dok je 20,60\% muškaraca, dijagnostika vršena kranijalnom kompjuterizovanom tomografijom. Kod 27,78\% muškaraca starijih od 80 godina bila je potrebna hitna medicinska pomoć usled intrakranijalnih procesa u ekspanziji i šloga. Procenat žena koje boluju od tumora $(55,17 \%)$ veći je nego kod muškaraca $(44,83 \%)$ u ovoj studiji. Razlika je statistički značajna $(\mathrm{p}<0,05)$.

Studija pokazuje da su kod muškaraca ispod 60 i žena ispod 40 godina starosti prisutne povrede, dok su kod pripadnika oba pola iznad navedene starosne dobi najprisutniji tumori. Na osnovu dobijenih rezultata, smatramo da je neophodno promovisati metode primarne prevencije kako bi se borili protiv faktora rizika i na taj način izbegli ozbiljne bolesti.

Ključne reči: medicinska antropologija, patologija, urgentnost. 